\title{
Growth hormone, insulin-like growth factor I and cell proliferation in the mouse blastocyst
}

\author{
K. E. Markham* and P. L. Kaye ${ }^{\dagger}$ \\ School of Biomedical Sciences, The University of Queensland, Brisbane, QLD 4072, Australia
}

\begin{abstract}
The role of growth hormone $(\mathrm{GH})$ in embryonic growth is controversial, yet preimplantation embryos express $\mathrm{GH}$, insulin-like growth factor I (IGF-I) and their receptors. In this study, addition of bovine GH doubled the proportion of two-cell embryos forming blastocysts and increased by about $25 \%$ the number of cells in those blastocysts with a concentration-response curve showing maximal activity at $1 \mathrm{pg}$ bovine $\mathrm{GH} \mathrm{ml}{ }^{-1}$, with decreasing activity at higher and lower concentrations. GH increased the number of cells in the trophectoderm by $25 \%$, but did not affect the inner cell mass of blastocysts. Inhibition of cell proliferation by anti-GH antiserum indicated that $\mathrm{GH}$ is a potent autocrine or paracrine regulator of the number of trophectoderm cells in vivo. Type 1 IGF receptors (IGF1 R) were localized to cytoplasmic vesicles and plasma membrane in the apical domains of uncompacted and
\end{abstract}

\section{Introduction}

Growth hormone $(\mathrm{GH})$ is an important embryonic growth regulator (Waters and Kaye, 2002). Perhaps the most marked evidence supporting this conclusion is that human Laron dwarf babies lacking GH receptor (GHR) are born more than two SD shorter than average (Laron et al., 1972) and that GH-deficient mice have reduced litter size with smaller fetuses (Danilovich et al., 1999). However, regulation of embryonic growth has traditionally been assigned to growth factors such as insulin and the insulin-like growth factors IGF-I and IGF-II.

Nonetheless, there is considerable evidence supporting a role for $\mathrm{GH}$ in embryo development. GHR mRNA has been detected in a range of extrapituitary fetal and placental tissues including the fetus and placenta in rats (Garcia-Aragon et al., 1992); sheep embryos at day 51 (Klempt et al., 1993), their trophectoderm and syncytium (Lacroix et al., 1999); and embryonic stem cells in mice (Ohlsson et al., 1993). GHR mRNA and protein are

\footnotetext{
*Present address: Department of Physiology, The University of Western Ontario, London ON6A 5C1, Canada

${ }^{\dagger}$ Correspondence

Email: p.kaye@uq.edu.au
}

compacted eight-cell embryos, but were predominantly apparent in cytoplasmic vesicles of the trophectoderm cells of the blastocyst, similar to GH receptors. Studies using $\alpha$ IR3 antiserum which blocks ligand activation of IGF1R, showed that IGF1R participate in the autocrine or paracrine regulation of the number of cells in the inner cell mass by an endogenous IGF-I-IGF1R pathway. However, $\alpha$ IR3 did not affect GH stimulation of the number of trophectoderm cells. Therefore, $\mathrm{GH}$ does not use secondary actions via embryonic IGF-I to modify the number of blastocyst cells. This result indicates that $\mathrm{GH}$ and IGF-I act independently. GH may selectively regulate the number of trophectoderm cells and thus implantation and placental growth. Embryonic GH may act in concert with IGF-I, which stimulates proliferation in the inner cell mass, to optimize blastocyst development. present in rats in multiple tissues before differentiation of the fetal pituitary (Garcia-Aragon et al., 1992). GH stimulates DNA synthesis in both the fetus and placenta of rats (Botero-Ruiz et al., 1997) and a variety of physiological responses demonstrate that isolated fetal tissues respond to GH (Nardo et al., 2000; Phornphutkul et al., 2000).

Proliferative responses to $\mathrm{GH}$ after birth are often mediated by IGF-I, the gene sequence of which contains a GH response activation site (Bichell et al., 1992). Mice deficient in either IGF-I or type 1 IGF receptors (IGF1R) show retarded fetal growth or die soon after birth (Liu et al., 1993; Baker et al., 1996). In addition to $\mathrm{GH}$ and GHR, mouse embryos express IGF-I mRNA (Doherty et al., 1994) and IGF1R mRNA (Rappolee et al., 1992; Schultz et al., 1992). Indeed, many of the preimplantation effects of IGF-I on embryos (Kaye et al., 1992) resemble those of $\mathrm{GH}$, indicating that $\mathrm{GH}$ may act via IGF-I.

The first embryonic cell proliferation and differentiation occurs before implantation while the embryo is moving through the reproductive tract. Over about 4 days, the mouse zygote cleaves and develops to a blastocyst consisting of a tight epithelial trophectoderm surrounding the inner cell mass (ICM) and blastocyst cavity. GHR is expressed by mouse zygotes and persists 
throughout preimplantation development (Terada et al., 1996; Pantaleon et al., 1997). GH mRNA first appears in morulae and the protein is localized to outer or apical cell membranes and cytoplasmic vesicles of blastocyst trophectoderm cells (Pantaleon et al., 1997). Furthermore, exogenous GH accelerates glucose transport and protein synthesis (Pantaleon et al., 1997) in an extremely sensitive and characteristic dose-dependent manner, with maximum effect at $0.1 \mathrm{ng} \mathrm{m}^{-1}$ for bovine $\mathrm{GH}$. GH supplementation in vitro increases the number of mouse blastocyst cells (Fukaya et al., 1998) and the rate of blastocyst formation (Drakakis et al., 1995; Montag et al., 2000). In cattle, GHR is expressed from day 2 and $\mathrm{GH}$ is expressed from day 8 (Kolle et al., 1998a,b, 2001; Izadyar et al., 2000). GH causes an increase in glycogen and lipid metabolism in bovine blastocysts (Kolle et al., 2001) and increases the number of cells in both the trophectoderm and ICM, apparently by an inhibition of apoptosis (Kolle et al., 2002). Whether this effect in cows also applies to mice, which are much more sensitive to $\mathrm{GH}$ and form a much smaller blastocyst, is unknown. Fertilization, cleavage rate and preimplantation outcome correlate with follicular fluid $\mathrm{GH}$ concentration (Mendoza et al., 1999) in human embryos generated by intracytoplasmic sperm injection. These data clearly implicate $\mathrm{GH}$ in the modulation of preimplantation development. A point of confusion arises from the use of human $\mathrm{GH}$ at much higher concentrations in mouse studies (Drakakis et al., 1995, 1996; Fukaya et al., 1998; Montag et al., 2000). These high-dose studies in mouse embryos should be repeated with non-primate $\mathrm{GH}$, as primate $\mathrm{GH}$ also activates the mouse prolactin receptor.

The functional relationship between $\mathrm{GH}$ and IGF-I in preimplantation embryos has not been investigated. Although $\mathrm{GH}$ receptors are expressed in cleavage stage embryos and in the trophectoderm and ICM cells of blastocysts (Pantaleon et al., 1997), similar studies localizing IGF1R are lacking. Furthermore, the target tissue for $\mathrm{GH}$ in the mouse blastocyst is not known, nor is it known whether embryonic GH or IGF-I act via autocrine or paracrine pathways to stimulate embryonic growth. The present study was designed to answer these questions.

\section{Materials and Methods}

\section{Embryo culture}

Quackenbush mice were randomly bred (lights on from 06:00 to 18:00 h) and used for experimentation with approval of the University of Queensland Animal Ethics and Experimentation Committee. Females (10 weeks of age) were superovulated by i.p. injection of 10 iu eCG at 10:00 $\mathrm{h}$ followed $48 \mathrm{~h}$ later by 10 iu hCG (Folligon \& Chorulon, Intervet, North Ryde) and paired individually with males. Mating was deter- mined by the presence of a vaginal plug at 09:00 $\mathrm{h}$ the following morning. Two-cell embryos were collected 48 $\mathrm{h}$ after injection with hCG and washed extensively in M2 (Fulton and Whittingham, 1978), modified according to Hobbs and Kaye (1985) to remove free hormones. The embryos were then cultured for $48-52 \mathrm{~h}$ in groups of different density in $20 \mu \mathrm{l}$ drops of BMOC2 (Brinster, 1965), modified according to Pemble and Kaye (1986), under liquid paraffin oil (Caltex Australia, Brisbane) at $37^{\circ} \mathrm{C}$ in a humidified atmosphere of $5 \% \mathrm{CO}_{2}$, 95\% air. In these conditions, two-cell embryos form blastocysts at the same rate as in vivo. Culture drops were supplemented as necessary with IGF-I (Gro-pep, Adelaide); recombinant bovine $\mathrm{GH}$ ( $\mathrm{rbGH}$, provided by A. F. Parlow, National Hormone and Peptide Program, NIDDKD, Harbor-UCLA Medical Centre, Torrance, CA); $\alpha I R 3$, an anti-IGF1R monoclonal antibody which blocks ligand binding to IGF1R (Calbiochem-Novabiochem, Croydon); or anti-rat $\mathrm{GH}$ ovine antiserum $(\alpha \mathrm{rGH}$, a gift from D. Flint, Hannah Research Institute, Ayr) which binds rodent, but not bovine, GH (Flint and Gardner, 1993). Each series consisted of three or more experiments with treatment groups of at least three drops containing two or more embryos in each.

\section{Total number of embryo cells in embryo spreads}

Blastocysts (96-100 h after injection with hCG) were removed from culture drops into $1 \%$ sodium citrate for 20 min on ice, air-dried onto slides with $\mathrm{CH}_{3} \mathrm{COOH}$ : $\mathrm{CH}_{3} \mathrm{CH}_{2} \mathrm{OH}(1: 3)$ and stained with giemsa (Tarkowski, 1966). Nuclei in the embryo spreads were then counted to assess the total number of cells in each embryo.

\section{Differential staining of ICM and trophectoderm nuclei}

After culture, the nuclei of cells in the trophectoderm and ICM of blastocysts (96-100 h after injection with hCG) were counted after differential nuclear staining (Handyside and Hunter, 1984). The zonae pellucidae were removed in acidic Tyrode's solution $(\mathrm{pH} 2.5)$ before incubation in $10 \%$ anti-mouse serum, prepared by immunization of a rabbit with mouse spleen cells according to Harvey and Kaye (1990), in M2 for 20 min at $37^{\circ} \mathrm{C}$ (Solter and Knowles, 1975). Embryos were then washed with $\mathrm{M} 2$ and incubated for $5 \mathrm{~min}$ at $37^{\circ} \mathrm{C}$ with $10 \mathrm{mg}$ propidium iodide $\mathrm{I}^{-1}$ (Sigma-Aldrich, Castle Hill) and $10 \%$ dilution of guinea-pig serum (Institute of Medical and Veterinary Science, Adelaide) as a source of complement. The embryos were washed briefly in $10 \mathrm{mmol}$ phosphate buffer $\mathrm{I}^{-1}(\mathrm{pH}$ 7.2) containing $137 \mathrm{mmol} \mathrm{NaCl} \mathrm{I}^{-1}$ and $2.7 \mathrm{mmol} \mathrm{KCl} \mathrm{I}{ }^{-1}$ (PBS) before being transferred to absolute ethanol with $25 \mathrm{mg}$ bisbenzimide $\mathrm{I}^{-1}$ (Hoechst 33258; Sigma-Aldrich), and were then left overnight at $4{ }^{\circ} \mathrm{C}$. The morning after, the embryos were washed with ethanol before mounting in a hanging drop of glycerol and were visualized under a 
Zeiss Photomicroscope 2 fitted with a HBO 50W highpressure mercury lamp. The trophectoderm nuclei were stained red using an excitation filter set comprising band pass interference exciter filter 546/12, barrier filter LP 590 and chromatic beam splitter FT 580 (Zeiss). The nuclei of both cell populations were visible with blue-violet excitation (filter set comprising band pass interference exciter filter G 365, barrier filter LP 420 and chromatic beam splitter FT 395; Zeiss); the trophectoderm nuclei were pink and the ICM nuclei blue (Harvey and Kaye, 1990).

\section{Whole mount immunostaining for IGF1R}

Embryos were collected 72 and $96 \mathrm{~h}$ after injection with hCG, fixed in $2 \%$ paraformaldehyde in PBS for $20 \mathrm{~min}$ at room temperature $\left(27^{\circ} \mathrm{C}\right)$, then washed in PBS before being placed on CellTak (Collaborative Biomedical Products, Bedford, MA) coated chambers. Fixed embryos were permeabilized in $0.25 \%$ Triton X-100 (Sigma-Aldrich) in PBS for $15 \mathrm{~min}$ at room temperature, neutralized with $0.05 \mathrm{~mol} \mathrm{NH}_{4} \mathrm{Cl} \mathrm{I}^{-1}$ in PBS for $10 \mathrm{~min}$, washed, then incubated in PBS containing $10 \%$ normal goat serum (NGS, obtained from goats bred at the laboratory), 1\% Tween 20 (ICN Biomedicals Australasia, Pty Ltd, Seven Hills) and $4 \mathrm{~g}$ bovine serum albumin $\mathrm{I}^{-1}$ (Trace Scientific Ltd, Noble Park, Victoria) for $60 \mathrm{~min}$ (NGS-Tween-BSA-PBS). Blocked embryos were incubated at $4{ }^{\circ} \mathrm{C}$ overnight with $0.13 \%$ rabbit polyclonal IgG raised against the extracellular amino terminal of the $\alpha$ chain of the IGF1R that does not crossreact with the $\beta$ chain or the IGF1R (product number sc-712; Santa Cruz Biotechnology, Santa Cruz, CA), diluted in 5\% NGS-Tween-BSA-PBS. After incubation in primary antibody, embryos were washed in TweenBSA-PBS and exposed for $60 \mathrm{~min}$ at room temperature to Texas-red conjugated secondary antibody (CalbiochemNovabiochem, Sydney) diluted in PBS. Finally, after washing with PBS, embryos were mounted in CitiFluor anti-fade solution (CityFluor Ltd, London) and viewed under a Bio-Rad MRC600 confocal scanning laser microscope mounted on a Zeiss Axioskop equipped with a Zeiss Plan-Apochromat $\times 40$ oil-immersion objective.

\section{Statistical analysis}

Data were analysed by factorial ANOVA for treatment, experiment and interaction effects. Differences between treatment means were tested for significance using Fischer's least squares significant difference post hoc test with the Statgraphics statistical package (Manugistics Inc, Rockville, MD). Means are presented with SEM. Categorical data are presented as percentage blastocyst formed and analysed using chi-squared test in Prism 3 for Macintosh (GraphPad Software Inc., San Diego, CA).

\section{Results}

\section{Localization of IGF1R in preimplantation embryos}

The high resolution of the laser scanning confocal microscope reveals the distribution of IGF1 R in embryos in whole mount (Fig. 1). Although occasional four-cell embryos (not shown) stained for IGF1R, IGF1R were first consistently detected in eight-cell embryos in the outer facing membrane or cortical cytoplasmic vesicles, just beneath the plasma membrane (Fig. 1a). This outer or apical localization persisted through compaction (Fig. 1a,b). A day later, IGF1R in blastocysts were mostly confined to cytoplasmic vesicles in trophectoderm cells. There was weak vesicular staining in the ICM, and some staining of plasma membranes adjacent to trophectoderm cells (Fig. 1c).

\section{Effects of GH on blastocyst formation and growth: concentration response}

GH markedly increased blastocyst formation. By 96$100 \mathrm{~h}$ after injection with hCG, in conditions of low density (five embryos per $20 \mu \mathrm{l}$ drop), 59\% of two-cell embryos formed blastocysts in medium containing $1 \mathrm{pg}$ $\mathrm{rbGH} \mathrm{ml} \mathrm{m}^{-1}$, almost twice as many as in the absence of $\mathrm{GH}\left(34 \%, P<0.01, \chi^{2}=8.665, n=65,73\right.$, three experiments). The use of rbGH, which unlike primate $\mathrm{GH}$ does not bind to the mouse prolactin receptor, eliminated a potentially confounding effect from these studies. Accompanying this increase in blastocyst formation was a $27 \%$ increase $(P<0.05)$ in the total number of cells with $1 \mathrm{pg} \mathrm{rbGH} \mathrm{ml}{ }^{-1}$ in a bell-shaped response curve, such that there was no significant response below $0.1 \mathrm{pg}$ $\mathrm{ml}^{-1}$ or above $10 \mathrm{pg} \mathrm{ml}^{-1}$ (Fig. 2).

\section{Autocrine or paracrine actions of $\mathrm{GH}$}

Embryos developing at a density of five embryos per $20 \mu \mathrm{l}$ droplet exhibited retarded growth compared with those developing in denser cultures (data not shown), indicating that endogenous autocrine or paracrine systems were diluted out when embryos were cultured in these conditions of low density. Embryos were incubated at high density (20 embryos per $20 \mu \mathrm{l}$ drop) to maximize autocrine or paracrine effects and $0.1 \% \alpha \mathrm{rGH} \operatorname{lgG}$ or non-immune sheep IgG was added (Fig. 3) to test whether $\mathrm{GH}$ was part of such an autoregulatory system. Compared with both medium alone and supplementation with non-immune sheep IgG, the blastocysts developing in the presence of $\alpha \mathrm{rGH}$ contained $13-17 \%$ fewer cells $(P<0.05)$.

\section{Differential effects of rbGH on blastocyst cell populations}

As all cells of the embryo express $\mathrm{GH}$ receptors, the tissue lineage, that is, ICM or trophectoderm that 

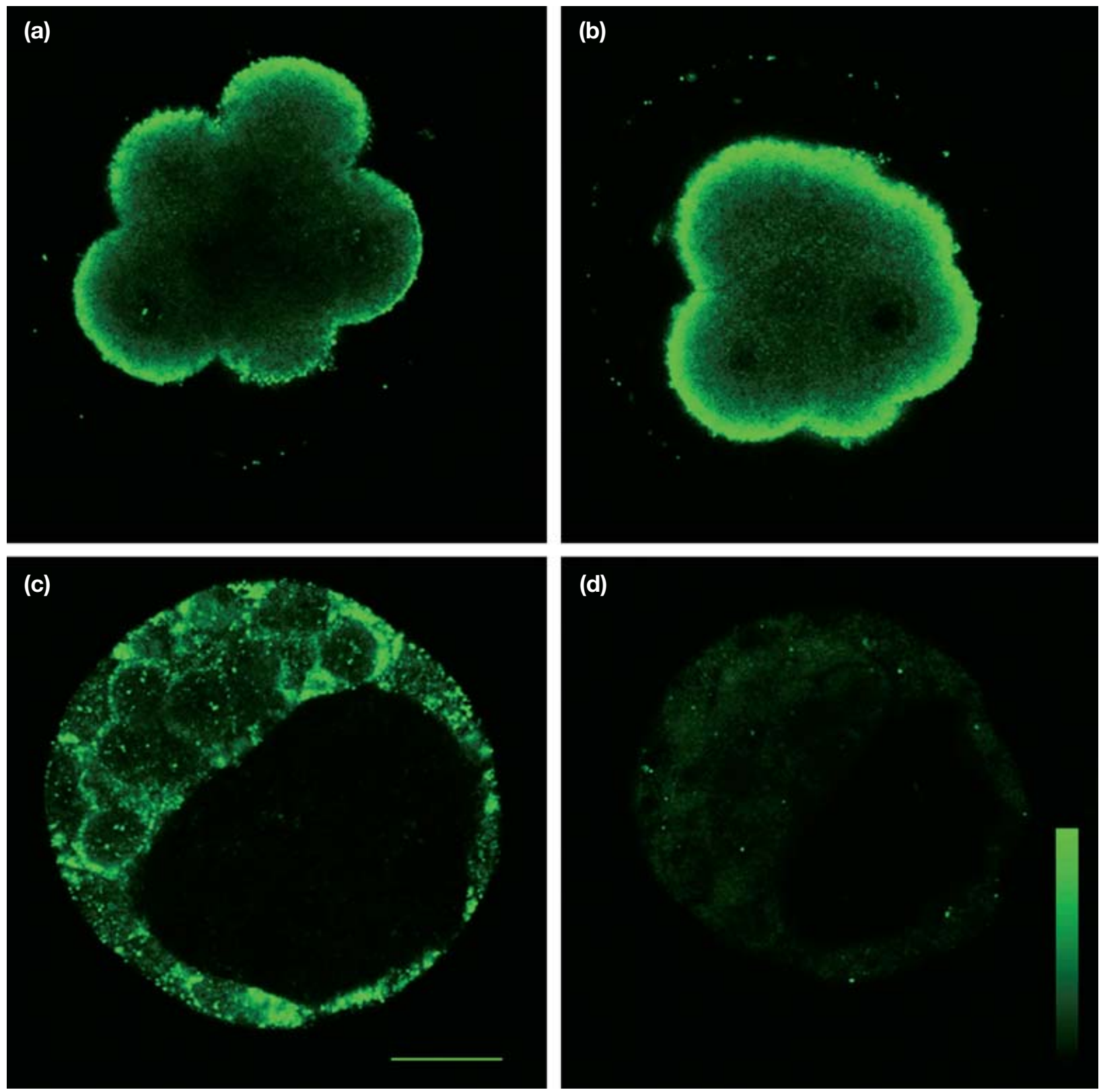

(d)

Fig. 1. Localization of type 1 insulin-like growth factor receptors in preimplantation mouse embryos. (a) Eight-cell embryo collected $72 \mathrm{~h}$ after injection with hCG; (b) early morula collected $72 \mathrm{~h}$ after injection with hCG; (c) blastocyst collected $96 \mathrm{~h}$ after injection with hCG; (d) normal rabbit IgG used as primary antibody for staining blastocysts $96 \mathrm{~h}$ after injection with hCG. Bright green colouring indicates most intense staining. Scale bar represents $25 \mu \mathrm{m}$.

responded to $\mathrm{GH}$ with increased proliferation, was determined. Blastocysts developing from the two-cell

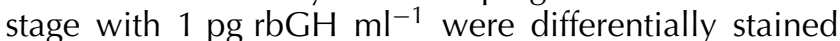
and cell populations were counted. The trophectoderm of GH-treated blastocysts contained five cells more than the untreated blastocysts $(25 \%, P<0.01$, Fig. 4$)$. Although there was an increase of approximately one cell (about $8 \%$ ) in the ICM, this was not significant (Fig. 4, $P>0.05)$. Thus, rbGH selectively stimulated trophectoderm cell population growth with no effect on ICM growth.
Does $\alpha$ IR3 block embryonic IGF-I: an autocrine or paracrine IGF-I circuit?

In addition to neutralizing the activity of human IGF1R, $\alpha$ IR3 also effectively prevents signalling mediated by IGF1R in preimplantation mouse embryos (Chi et al., 2000). It was necessary to show that $\alpha$ IR3 blocks the effects of IGF-I on ICM growth, to resolve effects arising directly through activation of GHR from those arising subsequent to $\mathrm{GH}$-induced IGF-I activation of IGF1R. A preliminary experiment indicated that 


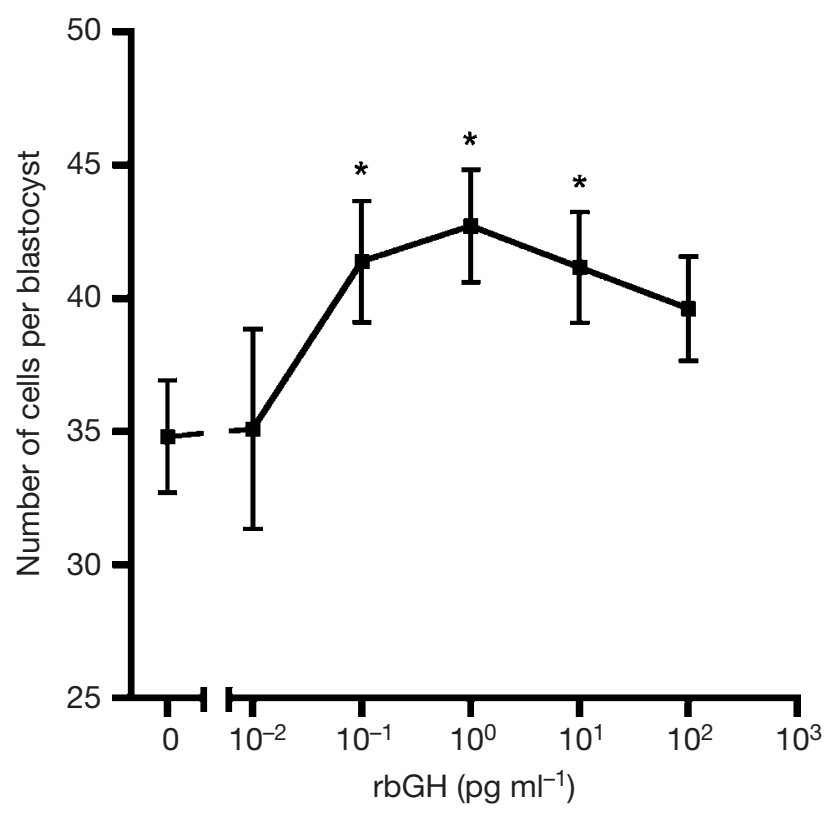

Fig. 2. Concentration response of number of mouse cells per blastocyst to recombinant bovine growth hormone (rbGH). Twocell embryos ( $48 \mathrm{~h}$ after injection with hCG) were collected and cultured for 96-100 $\mathrm{h}$ after injection with hCG, at five embryos per $20 \mu \mathrm{l}$ in BMOC2, with different concentrations of rbGH and number of cells per blastocyst. ${ }^{*} P<0.05$ by Fischer's test after twoway ANOVA for three experiments and concentrations $(\geqslant$ three blastocysts per concentration per experiment).

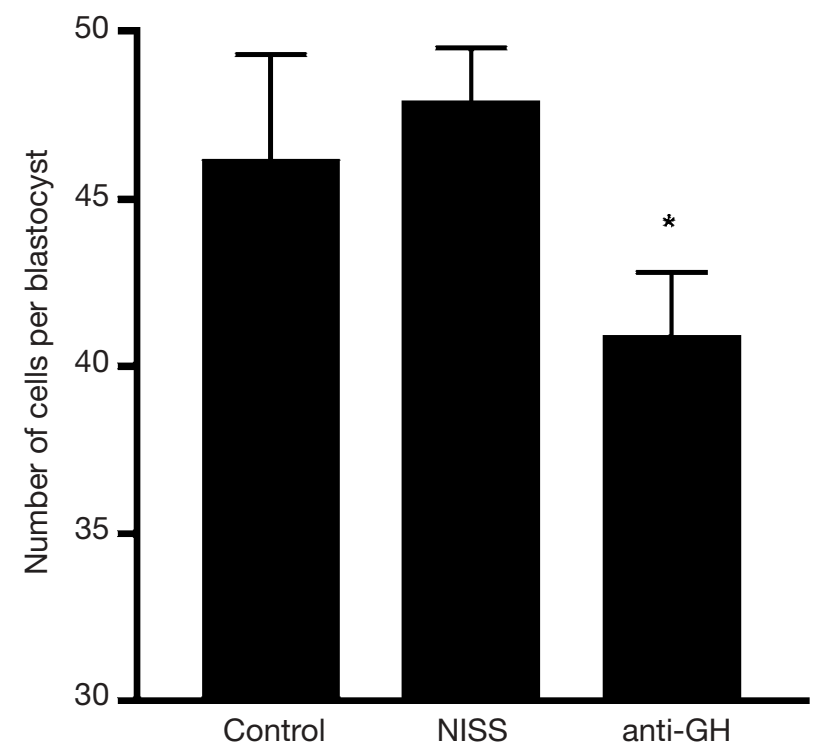

Fig. 3. Effects of anti-growth hormone $(\mathrm{GH})$ antibody on the number of mouse cells per blastocyst. Two-cell embryos (48 h after injection with hCG) were collected and cultured for 96-100 h after injection with hCG, at 20 embryos per $20 \mu \mathrm{l}$ drop of BMOC2 (control) or BMOC2 + non-immune sheep IgG (NISS), or BMOC2 + sheep anti- $\alpha \mathrm{rGH} \operatorname{lgG}($ anti-GH). The number of cells per blastocyst was counted. ${ }^{*} P<0.05$ by Fischer's test after two-way ANOVA for experiment and treatment (four experiments with $\geqslant$ five blastocysts per treatment per experiment).

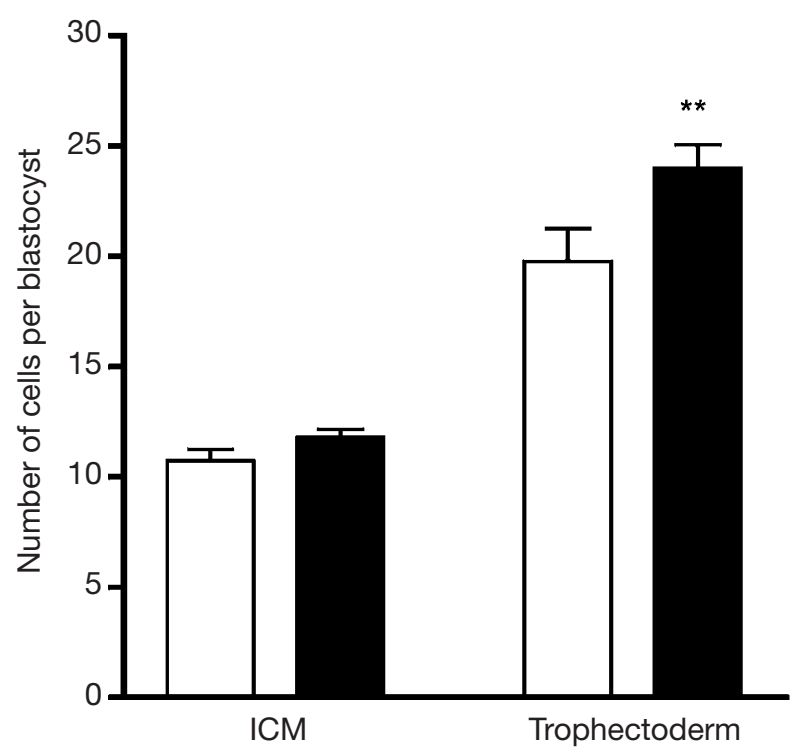

Fig. 4. Effects of growth hormone $(\mathrm{GH})$ on mouse blastocyst cell lineages. Two-cell embryos ( $48 \mathrm{~h}$ after injection with hCG) were cultured in groups of five per $20 \mu \mathrm{l}$ drop of BMOC2 with 0 ( $\square$ ) or $1 \mathrm{pg}$ recombinant bovine $\mathrm{GH} \mathrm{ml} \mathrm{m}^{-1}(\mathbf{\square})$ for $96-100 \mathrm{~h}$ after injection with hCG. The numbers of cells in the inner cell mass (ICM) and trophectoderm were counted. ${ }^{* *} P<0.01$ by Fischer's test after two-way ANOVA for experiment (six) and treatment ( $>$ four blastocysts per treatment in each).

whereas $1 \mu \mathrm{g} \alpha \mathrm{IR} 3 \mathrm{ml}^{-1}$ reduced the number of cells compared with BMOC2 alone $(11 \pm 1,8$ blastocysts versus $13 \pm 1,7$ blastocysts), $10 \mu \mathrm{g} \alpha \mathrm{IR} 3 \mathrm{ml}^{-1}$ produced a significant decrease $(10 \pm 1,10$ blastocysts, ANOVA, $P<0.05)$.

IGF-I stimulated the number of ICM cells by about two cells $(20 \%, P<0.05)$ and this was completely blocked by simultaneous presence of $10 \mu \mathrm{g} \alpha \mathrm{IR} 3 \mathrm{ml}^{-1}$ throughout the culture (Fig. 5b), confirming that mouse ICM IGF1R reflects $\alpha$ IR3 susceptibility characteristic of other tissues (Fig. 5). The data also show that culturing embryos in the presence of $\alpha$ IR3 but without IGF-I produced blastocysts with $10 \%(P<0.05)$ fewer ICM cells than those developing in unsupplemented medium. IGF-I was ineffective in the presence of $\alpha$ IR3 (Fig. 5b). Analysis of the number of trophectoderm cell responses to IGF-I and $\alpha$ IR3 confirmed that these cells were refractive of IGF-I (Fig. 5c). There was no significant change in the number of trophectoderm cells due to the presence of exogenous IGF-I, nor was $\alpha$ IR3 effective on trophectoderm, alone or in combination with IGF-I. Thus, $\alpha$ IR3 neutralized embryonic response to both endogenous and exogenous IGF-I, allowing it to be used to discriminate effects of $\mathrm{GH}$ mediated through IGF-I from effects resulting directly from $\mathrm{GH}$ receptor activation. 
(a)

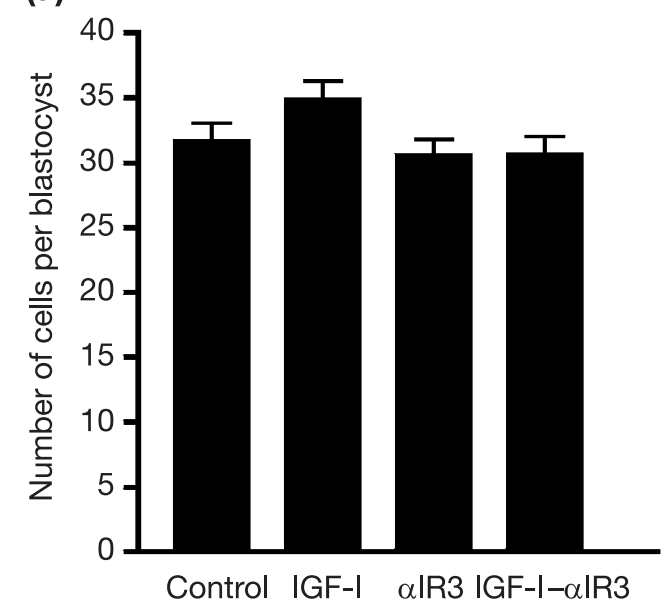

(b)

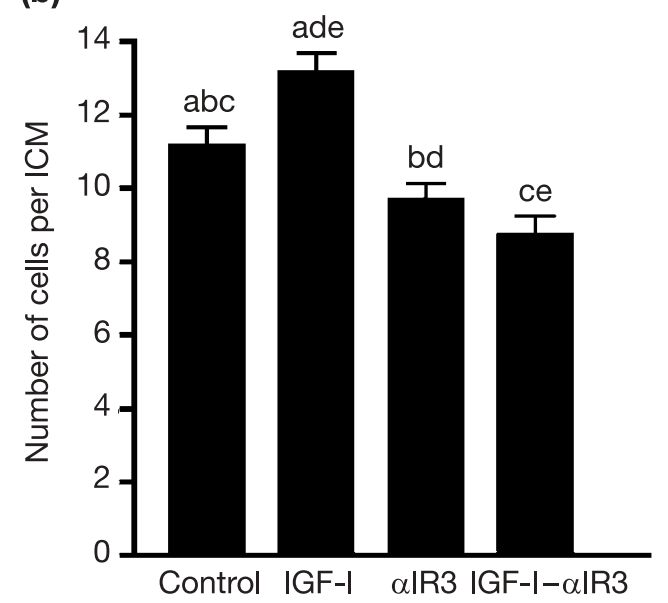

(c)

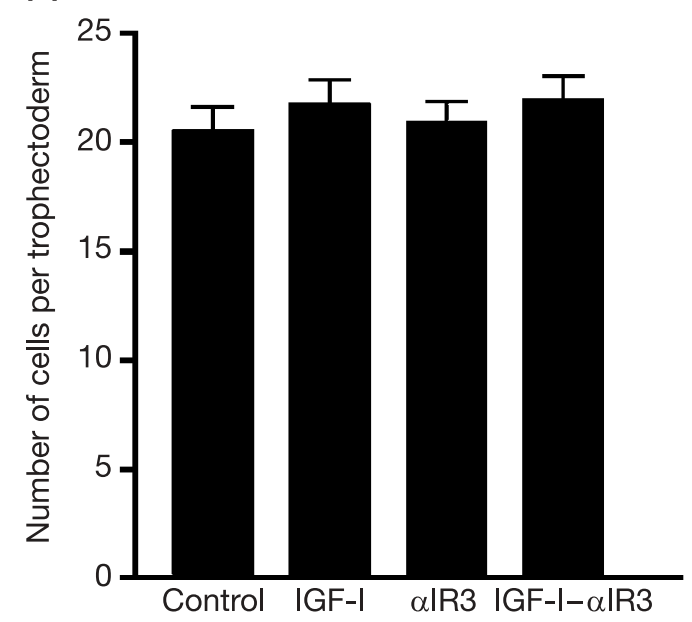

Fig. 5. Effects of insulin-like growth factor I (IGF-I) and $\alpha$ IR3 antitype 1 IGF receptor (IGF1R) antibody on the number of mouse cells per blastocyst. Two-cell embryos ( $48 \mathrm{~h}$ after injection with hCG) were collected and cultured in BMOC2 (control), BMOC2 + $1.7 \mathrm{nmol}$ IGF-I I ${ }^{-1}$ (IGF-I), BMOC2 + $\alpha$ IR3 anti-IGF1R antiserum $(\alpha I R 3)$ or $\mathrm{BMOC} 2+1.7 \mathrm{nmol}$ IGF-I $\mathrm{I}^{-1}+\alpha \mathrm{IR} 3 \quad$ (IGF-I- $\alpha$ IR3). (a) Total and differential cell counts in (b) inner cell mass (ICM) and (c) trophectoderm were performed at 96-100 $\mathrm{h}$ after injection
Does IGF-I downstream of GH stimulate trophectoderm cell proliferation?

Embryos cultured in the presence of $1 \mathrm{pg} \mathrm{GH}$ $\mathrm{ml}^{-1}$ contained about seven more cells than control blastocysts $(25 \%, P<0.01$, Fig. 6a; see also Fig. 2$)$. This effect of $\mathrm{GH}$ on total number of cells persisted in the presence of $\alpha$ IR3. Blocking IGF1R had no impact on the $\mathrm{GH}$-stimulated blastocyst growth (Fig. 6). The hypothesis that $\mathrm{GH}$ induces synthesis of IGF-I and its subsequent stimulation of IGF1R, was tested by counting separately the blastocyst trophectoderm and ICM populations after stimulation with $\mathrm{GH}$ in the presence of $\alpha I R 3$. GH did not affect the ICM, whereas addition of $\alpha$ IR3 inhibited ICM growth by about $20 \%(P<0.01$, Fig. 6 b). GH completely overcame this $\alpha$ IR3-induced inhibition of ICM growth (Fig. 6b). In the trophectoderm, $1 \mathrm{pg} \mathrm{GH} \mathrm{ml}^{-1}$ promoted growth of five or six more cells $(33 \%, P<0.01)$, irrespective of the presence of $\alpha \mid R 3$, which was ineffective alone (Fig. 6c).

\section{Discussion}

The results of the present study reveal $\mathrm{GH}$ to be an endogenous growth factor for trophectoderm cell proliferation via GHR, excluding participation of IGF-I. IGF1R were distributed to the apical domains of the morulae and cytoplasm of trophectoderm cells, indicating that they were arrayed to received ligands secreted by the maternal epithelium or by the embryo itself. Operation of an endogenous IGF-I-IGF1R pathway was also demonstrated by the studies with the IGF1R blocking antibody, $\alpha$ IR3.

Although IGF1R mRNA expression at the morula stage has been described in mice (Rappolee et al., 1992), studies of expression and localization of the protein in mouse embryos are limited. In morulae, IGF1R were concentrated in the apical or outer facing domains of the embryo. Upon blastocyst formation, IGF1R were predominantly found in cytoplasmic vesicles in trophectoderm cells, reflecting apical location in the morulae. Supporting these findings, an earlier immunoelectron microscopic study of blastocysts found IGF1R located in the basolateral membranes and cytoplasmic vesicles of trophectoderm cells (Smith et al., 1993). Furthermore, under IGF-I treatment, IGF1R were also present in the apical trophectoderm membranes (Chi et al., 2000). As IGF-I exclusively stimulates the number of cells of the ICM (Harvey and Kaye, 1992), this implies that the trophectoderm receptors transcytose IGF-I across the trophectoderm to bind to ICM receptors, leading

with hCG. Means with the same letter are significantly different; $P<0.05$ by Fischer's test after two-way ANOVA for experiment and treatment (three experiments with $\geqslant$ six blastocysts per treatment per experiment). 

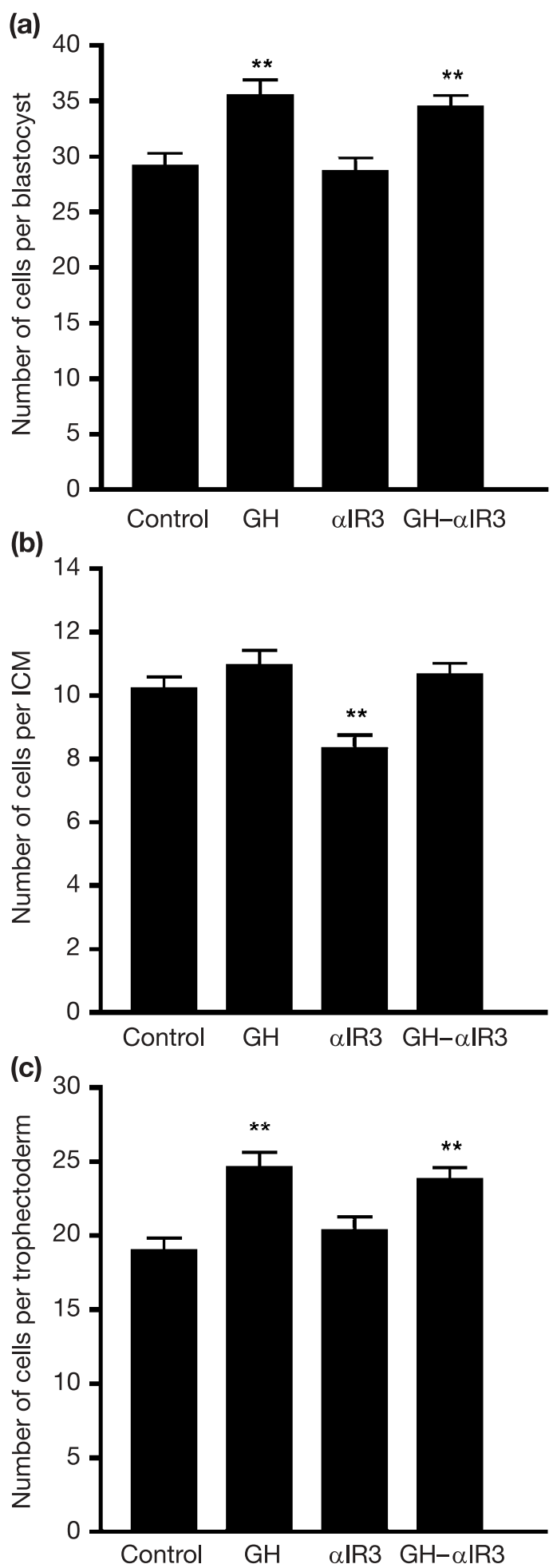

Fig. 6. Effects of growth hormone $(\mathrm{GH})$ and $\alpha \mathrm{IR} 3$ anti-type 1 IGF receptor (IGF1R) antiserum on the number of mouse cells per blastocyst. Two-cell embryos (48 h after injection with hCG) were collected and cultured in BMOC2 (control), BMOC2 + 1 pg recombinant bovine $\mathrm{GH}(\mathrm{rbGH}) \mathrm{ml}^{-1}(\mathrm{GH}), \mathrm{BMOC} 2+\alpha \mathrm{IR} 3$ antiIGF1R antiserum ( $\alpha$ IR3), or BMOC2 $+1 \mathrm{pg} \mathrm{rbGH} \mathrm{ml}^{-1}+\alpha \mathrm{IR} 3$

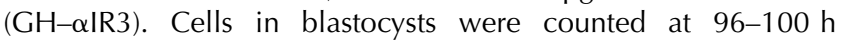
after injection with hCG. (a) Total and differential cell counts to an increased number of ICM cells. Movement of labelled IGF-I along this pathway has been visualized using electron microscopy (Smith et al., 1993).

In the present study, GH markedly increased the proportion of embryos forming blastocysts and the number of cells in those blastocysts. In particular, GH selectively targeted growth of the trophectoderm population independently of IGF-1R action, producing a tissue with $25 \%$ more cells. The growth of mouse trophectoderm is extremely sensitive to $\mathrm{GH}$, with maximum response in the range of $0.1-10 \mathrm{pg} \mathrm{ml}^{-1}$, at least one order of magnitude more sensitive than in earlier reports. The present results confirm other reports that $\mathrm{GH}$-induced increases in the number of blastocyst cells arise through actions mediated by the mouse $\mathrm{GH}$ receptor (Fukaya et al., 1998). The characteristic bell-shaped doseresponse curve for $\mathrm{rbGH}$ and the sensitivity of the embryonic receptor signalling system eliminate any possibility that $\mathrm{GH}$ actions were mediated by crossreaction with the mouse prolactin receptor. This was a possible confounder in earlier results which used higher doses of human GH (Drakakis et al., 1995, 1996; Fukaya et al., 1998) that may bind to the mouse prolactin receptor. The high sensitivity of the mouse $\mathrm{GH}$ receptor in the present study may have arisen from the experimental conditions, including the use of the simple medium BMOC. However, others have reported similar effects in mice as well as cattle, using more complex media including medium 199 and Ham's F10 (Drakakis et al., 1995, 1996; Fukaya et al., 1998; Kolle et al., 2001, 2002).

An important developmental observation in the present study is that $\mathrm{GH}$ caused growth of the epithelial trophectoderm, formed by the first round of cellular differentiation during preimplantation development. This epithelium generates ionic and osmotic gradients that draw extracellular fluid into the morula creating the blastocyst cavity. The blastocyst cavity is essential for implantation as it provides the necessary topography on which subsequent differentiation occurs. Cells developing from the trophectoderm invade the maternal endometrium, providing direct access to maternal nutrients necessary for continued embryo growth and development. Thus, GH may have an important role in promoting blastocyst formation and implantation. In support of this concept, blastocyst hatching from the zona pellucida is accelerated by $\mathrm{GH}$ (Drakakis et al., 1996; Fukaya et al., 1998; Montag et al., 2000) and greater numbers of blastocysts that develop in vitro in the presence of $\mathrm{GH}$ than untreated blastocysts implant after embryo transfer (Fukaya et al., 1998). $\mathrm{GH}$ induces expression of matrix metalloproteinases

in (b) inner cell mass (ICM) and (c) trophectoderm. ${ }^{* *} P<0.01$ by Fischer's test after two-way ANOVA for experiment and treatment (three experiments with $\geqslant$ four blastocysts per treatment per experiment). 
(MMP) (Thompson et al., 2000) that may be involved in implantation (Harvey et al., 1995a; Whiteside et al., 2001). Perhaps $\mathrm{GH}$, like leukaemia inhibitory factor, is another soluble factor stimulating secretion of MMP from trophectoderm cells (Harvey et al., 1995b), facilitating hatching and implantation.

The simultaneous presence in the eight-cell morula of the four participants in a GH-IGF-I paracrine loop present the possibility that IGF-I and IGF1R act as intermediates in trophectoderm hyperplasia promoted by $\mathrm{GH}$. However, because the IGF1R blocking antibody $(\alpha I R 3)$ and $\mathrm{GH}$ affect the number of cells of different blastocyst cell populations, this possibility is highly unlikely. The other reported effects of $\mathrm{GH}$ during preimplantation embryogenesis are also functions of the trophectoderm; that is, stimulation of glucose uptake (Pantaleon et al., 1997) and blastocyst formation (the present study; Drakakis et al., 1995; Fukaya et al., 1998; Montag et al., 2000). GH therefore appears to be targeted specifically at modifying trophectoderm physiology, whereas IGF-I affects both cell populations but stimulates only ICM growth (Kaye et al., 1992; Kaye and Harvey, 1995; Kaye, 1997).

In human (Spanos et al., 2000), rabbit (Herrler et al., 1998) and mouse embryos (Chi et al., 2000), IGF-I increases ICM growth by inhibiting apoptosis, which is a more common feature of the ICM than trophectoderm (Pampfer, 2000). Therefore, it is more likely that growth in the trophectoderm population, induced by $\mathrm{GH}$, arises from proliferative actions rather than anti-apoptotic actions, although this remains to be determined. Indeed, in bovine embryos, GH stimulates growth of both the ICM and trophectoderm through inhibition of apoptosis (Kolle et al., 2002). Blocking IGF1R of otherwise unsupplemented embryos causes the development of blastocysts with a smaller ICM. Thus, an embryonic IGF-I-IGF1R circuit inhibits apoptosis in preimplantation embryos. It has been suggested that IGF-I expression (presumably acting in this circuit) correlates with embryo viability after culture and transfer (Kowalik et al., 1999). It is clear that activation of such an endogenous embryonic IGF-I loop is not the means by which $\mathrm{GH}$ stimulates trophectoderm hyperplasia.

The present study has shown that, although ineffective on the ICM of embryos cultured with an intact IGF1R, GH could compensate for the $\alpha$ IR3 blockade on ICM growth. This might reflect an anti-apoptotic effect of GH on ICM (Kolle et al., 2002). GH is anti-apoptotic in other cell lines (Costoya et al., 1999; Baixeras et al., 2001). Perhaps $\mathrm{GH}$ or an intermediate factor crosses the trophectoderm to maintain cell proliferation by inhibiting apoptosis in the ICM.

In conclusion, $\mathrm{GH}$ has been shown to be an important preimplantation embryonic growth factor promoting proliferation of the trophectoderm with implications for subsequent implantation of the blastocyst. This activity is independent of IGF1R. In contrast, IGF-I promotes
ICM growth through an autocrine or paracrine pathway. The operation of this IGF-I pathway is reflected in the localization of embryonic IGF1R to the outer facing domains of cleaving and compacting embryos and to the trophectoderm. Demonstration of these endogenous pathways of $\mathrm{GH}$ and IGF-I actions has important implications in the understanding of the physiology of early pregnancy and indicates potential improvements in media for in vitro culture of embryos.

Note added in proof: Moreira et al. (2002) used antiIGF-I rather than anti-IGF1R to show that $\mathrm{GH}$ acts independently of IGF-I to increase the number of cells in bovine blastocysts.

Moriera F, Paula-Lopes FF, Hansen PJ, Badinga L and Thatcher WW (2002) Effects of growth hormone and insulin-like growth factor I on development of in vitro derived bovine embryos Theriogenology $\mathbf{5 7}$ 895-907

The authors thank M. Pantaleon and M. Waters for helpful discussion, D. Flint for the gift of $\alpha \mathrm{rGH}$ antiserum, A. Parlow for the recombinant $\mathrm{bGH}$ and $\mathrm{C}$. Corcoran for supervising the Quackenbush mouse colony. This study was supported by project grant 981285 from National Health and Medical Research Council of Australia to P. L. Kaye.

\section{References}

Baixeras E, Jeay S, Kelly PA and Postel-Vinay MC (2001) The proliferative and antiapoptotic actions of growth hormone and insulin-like growth factor-I are mediated through distinct signaling pathways in the Pro-B $\mathrm{Ba} / \mathrm{F} 3$ cell line Endocrinology 142 2968-2977

Baker J, Hardy MP, Zhou J, Bondy C, Lupu F, Bellve AR and Efstratiadis A (1996) Effects of an Igf1 gene null mutation on mouse reproduction Molecular Endocrinology 10 903-918

Bichell DP, Kikuchi K and Rotwein P (1992) Growth hormone rapidly activates insulin-like growth factor I gene transcription in vivo. Molecular Endocrinology 6 1899-1908

Botero-Ruiz W, Biggers WJ and Sanyal MK (1997) Augmentation of DNA synthesis in placental and fetal tissues in utero by maternal growth hormone treatment Early Pregnancy 3 272-280

Brinster RL (1965) Studies on the development of mouse embryos in vitro. IV. Interaction of energy sources Journal of Reproduction and Fertility $\mathbf{1 0}$ 227-240

Chi MM, Schlein AL and Moley KH (2000) High insulin-like growth factor 1 (IGF-1) and insulin concentrations trigger apoptosis in the mouse blastocyst via down-regulation of the IGF-1 receptor Endocrinology 141 4784-4792

Costoya JA, Finidori J, Moutoussamy S, Searis R, Devesa J and Arce VM (1999) Activation of growth hormone receptor delivers an antiapoptotic signal: evidence for a role of Akt in this pathway Endocrinology $\mathbf{1 4 0}$ 5937-5943

Danilovich N, Wernsing D, Coschigano KT, Kopchick JJ and Bartke A (1999) Deficits in female reproductive function in GH-R-KO mice; role of IGF-I Endocrinology 140 2637-2640

Doherty AS, Temeles GL and Schultz RM (1994) Temporal pattern of IGF-I expression during mouse preimplantation embryogenesis Molecular Reproduction and Development 37 21-26

Drakakis P, Loutradis D, Milingos S, Michalas S, Kallianidis K, Bletsa R, Aravantinos D and Kiessling AA (1995) A preliminary study of the effect of growth hormone on mouse preimplantation embryo development in vitro. Gynecologic and Obstetric Investigation $40222-226$ 
Drakakis P, Loutradis D, Milingos S, Bletsa R, Kallianidis K, Michalas S and Aravantinos D (1996) The in vitro development of mouse embryos beyond the blastocyst stage into the hatching and outgrowth stage using different energy sources Journal of Assisted Reproduction and Genetics 13 786-792

Flint DJ and Gardner MJ (1993) Influence of growth hormone deficiency on growth and body composition in rats: site-specific effects upon adipose tissue development Journal of Endocrinology 137 203-211

Fukaya T, Yamanaka T, Terada Y, Murakami T and Yajima A (1998) Growth hormone improves mouse embryo development in vitro and the effect is neutralized by growth hormone receptor antibody Tohoku Journal of Experimental Medicine 184 113-122

Fulton BP and Whittingham DG (1978) Activation of mammalian oocytes by intracellular injection of calcium Nature 273 149-151

Garcia-Aragon J, Lobie PE, Muscat GE, Gobius KS, Norstedt G and Waters MJ (1992) Prenatal expression of the growth hormone $(\mathrm{GH})$ receptor/binding protein in the rat: a role for $\mathrm{GH}$ in embryonic and fetal development? Development 114 869-876

Handyside AH and Hunter S (1984) A rapid procedure for visualising the inner cell mass and trophectoderm nuclei of mouse blastocysts in situ using polynucleotide-specific fluorochromes Journal of Experimental Zoology 231 429-434

Harvey MB and Kaye PL (1990) Insulin increases the cell number of the inner cell mass and stimulates morphological development of mouse blastocysts in vitro. Development 110 963-967

Harvey MB and Kaye PL (1992) Insulin-like growth factor-1 stimulates growth of mouse preimplantation embryos in vitro. Molecular Reproduction and Development 31 195-199

Harvey MB, Leco KJ, Arcellana-Panlilio MY, Zhang X, Edwards DR and Schultz GA (1995a) Proteinase expression in early mouse embryos is regulated by leukaemia inhibitory factor and epidermal growth factor Development 121 1005-1014

Harvey MB, Leco KJ, Arcellana-Panlilio MY, Zhang X, Edwards DR and Schultz GA (1995b) Roles of growth factors during peri-implantation development Human Reproduction $10712-718$

Herrler A, Krusche CA and Beier HM (1998) Insulin and insulin-like growth factor-I promote rabbit blastocyst development and prevent apoptosis Biology of Reproduction 59 1302-1310

Hobbs JG and Kaye PL (1985) Glycine transport in mouse eggs and preimplantation embryos Journal of Reproduction and Fertility $\mathbf{7 4}$ 7786

Izadyar F, Van Tol HT, Hage WG and Bevers MM (2000) Preimplantation bovine embryos express mRNA of growth hormone receptor and respond to growth hormone addition during in vitro development Molecular Reproduction and Development 57 247-255

Kaye PL (1997) Preimplantation growth factor physiology Reviews of Reproduction 2 121-127

Kaye PL and Harvey MB (1995) The role of growth factors in preimplantation development Progress in Growth Factor Research 6 1-24

Kaye PL, Bell KL, Beebe LF, Dunglison GF, Gardner HG and Harvey MB (1992) Insulin and the insulin-like growth factors (IGFs) in preimplantation development Reproduction, Fertility and Development 4 373-386

Klempt M, Bingham B, Breier BH, Baumbach WR and Gluckman PD (1993) Tissue distribution and ontogeny of growth hormone receptor messenger ribonucleic acid and ligand binding to hepatic tissue in the midgestation sheep fetus Endocrinology 132 1071-1077

Kolle S, Sinowatz F, Boie G and Lincoln D (1998a) Developmental changes in the expression of the growth hormone receptor messenger ribonucleic acid and protein in the bovine ovary Biology of Reproduction 59 836842

Kolle S, Sinowatz F, Boie G, Lincoln D, Palma G, Stojkovic $M$ and Wolf E (1998b) Topography of growth hormone receptor expression in the bovine embryo Histochemistry and Cell Biology 109 417419

Kolle S, Stojkovic M, Prelle K, Waters M, Wolf E and Sinowatz F (2001) Growth hormone $(\mathrm{GH}) / \mathrm{GH}$ receptor expression and $\mathrm{GH}$-mediated effects during early bovine embryogenesis Biology of Reproduction 64 1826-1834
Kolle S, Stojkovic M, Boie G, Wolf E and Sinowatz F (2002) Growth hormone inhibits apoptosis in in vitro produced bovine embryos Molecular Reproduction and Development 61 180-186

Kowalik A, Liu HC, He ZY, Mele C, Barmat L and Rosenwaks Z (1999) Expression of the insulin-like growth factor- 1 gene and its receptor in preimplantation mouse embryos; is it a marker of embryo viability? Molecular Human Reproduction 5 861-865

Lacroix MC, Devinoy E, Cassy S, Servely JL, Vidaud M and Kann G (1999) Expression of growth hormone and its receptor in the placental and fetomaternal environment during early pregnancy in sheep Endocrinology 140 5587-5597

Laron Z, Karp M, Pertzelan A and Kauli R (1972) Insulin growth and growth hormone Israel Journal of Medical Sciences 8 440-452

Liu JP, Baker J, Perkins AS, Robertson EJ and Efstratiadis A (1993) Mice carrying null mutations of the genes encoding insulin-like growth factor I (Igf-1) and type 1 IGF receptor (Igf1 r) Cell 75 59-72

Mendoza C, Cremades N, Ruiz-Requena E, Martinez F, Ortega E, Bernabeu S and Tesarik J (1999) Relationship between fertilization results after intracytoplasmic sperm injection and intrafollicular steroid pituitary hormone and cytokine concentrations Human Reproduction 14 628635

Montag M, Koll B, Holmes P and van der Ven H (2000) Significance of the number of embryonic cells and the state of the zona pellucida for hatching of mouse blastocysts in vitro versus in vivo. Biology of Reproduction 62 1738-1744

Nardo L, Young IR and Hooper SB (2000) Influence of growth hormone on the lung growth response to tracheal obstruction in fetal sheep American Journal of Physiology. Lung Cellular and Molecular Physiology 278 L453-L459

Ohlsson C, Lovstedt K, Holmes PV, Nilsson A, Carlsson L and Tornell J (1993) Embryonic stem cells express growth hormone receptors: regulation by retinoic acid Endocrinology 133 2897-2903

Pampfer S (2000) Apoptosis in rodent peri-implantation embryos: differential susceptibility of inner cell mass and trophectoderm cell lineages - a review Placenta 21 S3-S10

Pantaleon M, Whiteside EJ, Harvey MB, Barnard RT, Waters MJ and Kaye PL (1997) Functional growth hormone $(\mathrm{GH})$ receptors and $\mathrm{GH}$ are expressed by preimplantation mouse embryos: a role for $\mathrm{GH}$ in early embryogenesis? Proceedings National Academy of Sciences USA 94 5125-5130

Pemble LB and Kaye PL (1986) Whole protein uptake and metabolism by mouse blastocysts Journal of Reproduction and Fertility $\mathbf{7 8} 149$ 157

Phornphutkul C, Frick GP, Goodman HM, Berry SA and Gruppuso PA (2000) Hepatic growth hormone signaling in the late gestation fetal rat Endocrinology 141 3527-3533

Rappolee DA, Sturm KS, Behrendtsen O, Schultz GA, Pedersen RA and Werb Z (1992) Insulin-like growth factor II acts through an endogenous growth pathway regulated by imprinting in early mouse embryos Genes and Development 6 939-952

Schultz GA, Hogan A, Watson AJ, Smith RM and Heyner S (1992) Insulin, insulin-like growth factors and glucose transporters: temporal patterns of gene expression in early murine and bovine embryos Reproduction, Fertility and Development 4 361-371

Smith RM, Garside WT, Aghayan M, Shi CZ, Shah N, Jarett L and Heyner S (1993) Mouse preimplantation embryos exhibit receptormediated binding and transcytosis of maternal insulin-like growth factor I Biology of Reproduction 49 1-12

Solter D and Knowles BB (1975) Immunosurgery of mouse blastocysts Proceedings National Academy of Sciences USA 72 5099-5102

Spanos S, Becker DL, Winston RM and Hardy K (2000) Anti-apoptotic action of insulin-like growth factor-I during human preimplantation embryo development Biology of Reproduction 63 14131420

Tarkowski AK (1966) An air drying method for chromosome preparations from mouse eggs Cytogenetics 5 394-400

Terada Y, Fukaya T, Takahashi M and Yajima A (1996) Expression of growth hormone receptor in mouse preimplantation embryos Molecular Human Reproduction 2 879-881 
Thompson BJ, Shang CA and Waters MJ (2000) Identification of genes induced by growth hormone in rat liver using cDNA arrays Endocrinology 141 4321-4324

Waters M and Kaye P (2002) The role of growth hormone in fetal development Growth Hormone and IGF Research 12 137-146

Whiteside EJ, Jackson MM, Herington AC, Edwards DR and Harvey MB (2001) Matrix metalloproteinase-9 and tissue inhibitor of metalloproteinase-3 are key regulators of extracellular matrix degra- dation by mouse embryos Biology of Reproduction 641331 1337

Received 6 August 2002.

First decision 7 November 2002.

Revised manuscript received 27 November 2002.

Accepted 29 November 2002. 